\title{
Diastereoselective functionalisation of benzo- annulated bicyclic sultams: Application for the synthesis of cis-2,4-diarylpyrrolidines
}

\author{
Susan Kelleher, Pierre-Yves Quesne and Paul Evans*
}

\section{Full Research Paper}

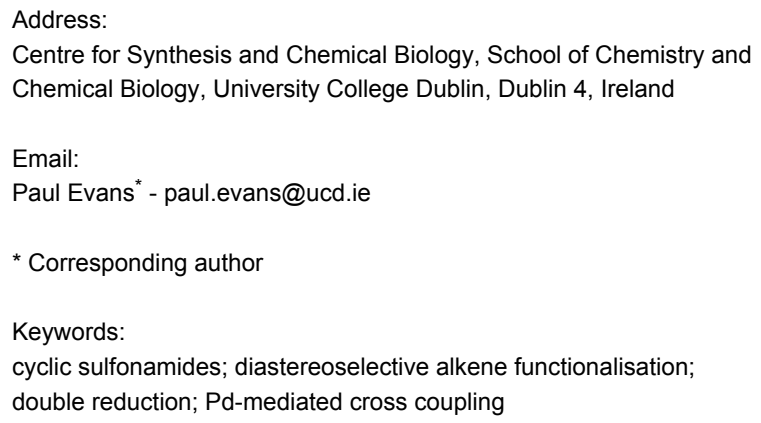

Beilstein Journal of Organic Chemistry 2009, 5, No. 69 doi:10.3762/bjoc.5.69

Received: 04 August 2009

Accepted: 08 October 2009

Published: 25 November 2009

Associate Editor: J. Aubé

(c) 2009 Kelleher et al; licensee Beilstein-Institut. License and terms: see end of document.

\begin{abstract}
The cis-dibromination of unsaturated bicyclic bridgehead sultams $\mathbf{5} \mathbf{a}$ and $\mathbf{5 b}$, and experiments designed to understand the cisstereochemical outcome of these reactions, are described. In the case of $\mathbf{5 b}$, a novel solvent dependent carbocation rearrangement occurs with the formation of $\mathbf{1 8 b}$. cis-Dibromides 13a and $\mathbf{1 3 b}$ undergo regioselective dehydrobromination, and the participation of the resultant vinyl bromide 24a in lithiation and Pd-coupling chemistry is described. In the case of the latter, hydrogenation of the styryl products afforded a single diastereoisomer. These compounds were then studied under dissolved metal reduction conditions, in which the cleavage of both $\mathrm{N}-\mathrm{S}$ and $\mathrm{C}-\mathrm{S}$ bonds takes place to afford cis-2,4-diaryl-substituted pyrrolidines 35-37.
\end{abstract}

\section{Introduction}

Substituted pyrrolidine ring systems represent a common structural motif in a range of biologically active compounds, including pharmaceutical agents and natural products. In relation to these general targets, we have recently developed a method that enables the construction of aryl-substituted pyrrolidines, featuring the double reduction of cyclic aromatic sulfonamides [1-4]. As illustrated in Scheme 1, a Heck (Heck-Mizoroki) cyclisation [5-9] was employed to form the cyclic sulfonamide. Subsequently, it was shown that high stereofacial bias was achieved on hydrogenation, generating 2 as a single diastereoisomer. Treatment under dissolved metal reduction conditions afforded the cis-disubstituted pyrrolidine.
In this sequence, the sulfonyl moiety not only serves as an amino protecting group but also facilitates the diastereoselective intramolecular carbon-carbon bond formation. In this present study we demonstrate that this general concept may be extended enabling the diastereoselective preparation of 2,4diaryl-substituted pyrrolidines from more readily available, albeit racemic, substrates.

\section{Results and Discussion}

Bicyclic aromatic cyclic sulfonamides $\mathbf{5 a}$ and $\mathbf{5 b}$ were formed according to the 3-step sequence previously described [1-3,10]. Originally, inclusion of triphenylphosphine was employed, 


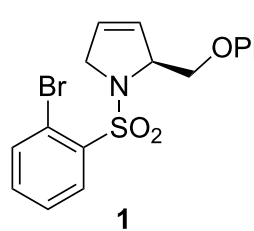

1 (i) $\mathrm{Pd}(\mathrm{OAc})_{2}(10 \mathrm{~mol} \%)$,

$\mathrm{PPh}_{3}(20 \mathrm{~mol} \%), \mathrm{K}_{2} \mathrm{CO}_{3}$,

DMF, $110^{\circ} \mathrm{C}, 61 \%$

(ii) $\mathrm{H}_{2}(1 \mathrm{~atm}), \mathrm{Pd} / \mathrm{C}(1 \mathrm{~mol} \%)$,

EtOAc, $90 \%$, >95\% de

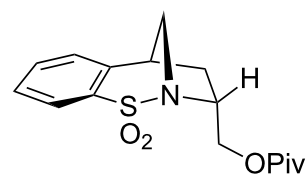

2

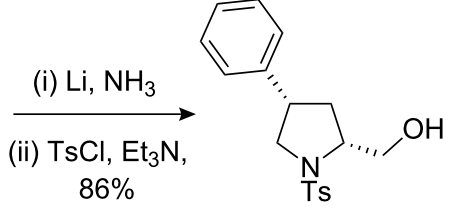

3

Scheme 1: The diastereoselective intramolecular Heck-hydrogenation and double reduction sequence as a means of accessing cis-disubstituted pyrrolidine 3 .

however, optimisation of this reaction with the exclusion of $\mathrm{PPh}_{3}$ gave products $5 \mathbf{a}$ and $\mathbf{5 b}$ in 82 and $65 \%$ yields, respectively, which are comparable with the phosphine-based method (5a: $84 \%$ and 5b: $76 \%$ with $\mathrm{PPh}_{3}$ ) [11]. Standard alkenyl hydrogenation (not shown) then gave the saturated bicycles $6 \mathbf{a}$ and $\mathbf{6 b}$ which were used as substrates for the $\mathrm{N}-\mathrm{S}$ and $\mathrm{C}-\mathrm{S}$ bond cleavage forming arylsubstituted pyrrolidines [1-3]. In relation to this sequence attempts to achieve a reductive Heck cyclisation employing ammonium formate [12], gave only the product of bromine-hydrogen exchange $\mathbf{4 c}$ (where $\mathrm{X}=\mathrm{H}$ ). Therefore, a one-pot method was developed based on recent reports which demonstrate that the residual palladium catalyst in Heck reactions may effectively mediate the addition of hydrogen to the newly substituted alkene [13-15]. Thus, following complete Heck cyclisation, as judged by TLC analysis, the reaction was simply stirred under a hydrogen atmosphere in order to afford the corresponding saturated bicycles $\mathbf{6 a}$ and $\mathbf{6 b}$ in yields of 61 and $52 \%$ respectively. In terms of efficiency this one-pot process is competitive compared with those from the original two-step, two-pot process (Scheme 2).

Functionalisation of the $N$-sulfonyl enamines $\mathbf{5 a}$ and $\mathbf{5 b}$ was subsequently studied with the ultimate aim of introducing substituents, in a stereoselective fashion, to the masked pyrrolidine ring. Thus, epoxidation of $\mathbf{5 a}$ and $\mathbf{5 b}$ (Scheme 3 ) using $m$-CPBA proceeded smoothly for both substrates and as

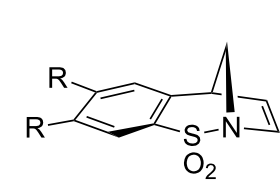

5a: $\mathrm{R}=\mathrm{H}, 84 \%(82 \%)$

5b: $R=O M e, 76 \%(65 \%)$

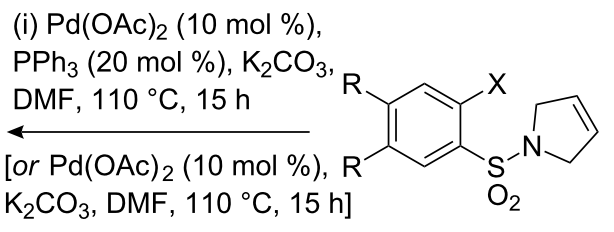

4a: $\mathrm{R}=\mathrm{H}, \mathrm{X}=\mathrm{Br}$

4b: $R=O M e, X=B r$

4c: $R=H, X=H$ (i) $\mathrm{Pd}(\mathrm{OAc})_{2}(10 \mathrm{~mol} \%)$,

$\mathrm{PPh}_{3}(20 \mathrm{~mol} \%), \mathrm{K}_{2} \mathrm{CO}_{3}$,

DMF, $110^{\circ} \mathrm{C}, 15 \mathrm{~h}$

(ii) $\mathrm{H}_{2}, \mathrm{rt}, 15 \mathrm{~h}$

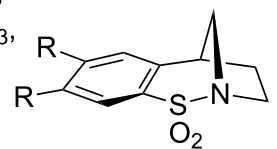

6a: $\mathrm{R}=\mathrm{H}, 61 \%$

6b: $R=O M e, 52 \%$

Scheme 2: The synthesis of $\mathbf{5 a}$ and $\mathbf{5 b}$ by an intramolecular Heck cyclisation reaction.<smiles>[R]c1cc2ccc1cc2[R]</smiles> 


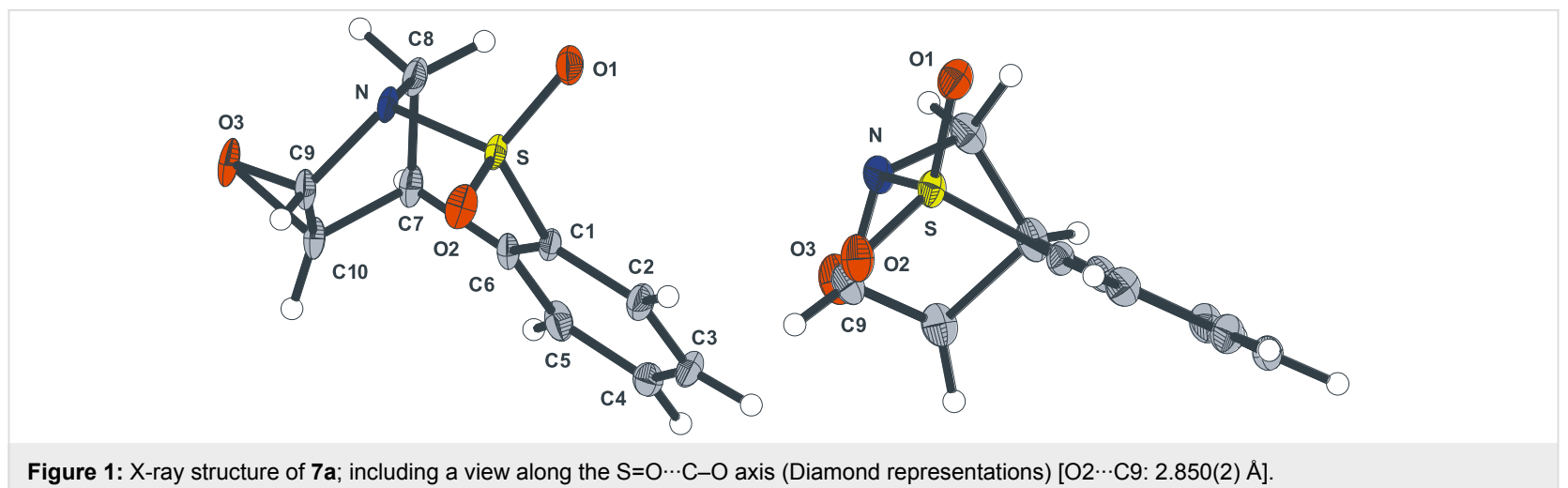

Figure 1: X-ray structure of $7 \mathrm{a}$; including a view along the $\mathrm{S}=\mathrm{O} \cdots \mathrm{C}-\mathrm{O}$ axis (Diamond representations) $[\mathrm{O} 2 \cdots \mathrm{C}$ : $2.850(2) \AA]$.

hoped, occurred under complete stereocontrol (de $>95 \%)$. The stereochemical outcome was confirmed by single-crystal X-ray crystallography (Figure 1, and see crystallographic data). The use of in situ generated trifluoromethyl-methyldioxirane was also investigated and in the case of $\mathbf{5 a}$, very efficient formation of $7 \mathbf{a}$ was observed [16,17].

Unfortunately, however, under a variety of conditions it proved impossible to elaborate these species. For example, reductive ring-opening using triethylsilane, conditions previously reported for $N$-sulfonylamino- $\alpha, \beta$-epoxides $[18,19]$, led only to recovery of starting material and not the hoped for alcohol 8 . A similar outcome was observed under both Sakurai-type conditions and treatment with potassium cyanide. It seems probable that these failures reflect a combination of the inability of the $N$-lone pair to stabilise the developing $\alpha$-carbocation (the resultant $N$-sulfonyl iminium ion would be anti-Bredt) and in addition the lone pair is perpendicular to the p-orbital resulting from $\mathrm{C}-\mathrm{O}$ bond cleavage. Furthermore, it also appears that the aromatic ring, based on the fold of the molecule, represents a steric barrier blocking the approach to the $\mathrm{C}-\mathrm{O} \sigma^{*}$ orbital. Since the bicyclic structure was implicated in the lack of epoxide reactivity, double reduction of $\mathbf{7 a}$ was then considered. It was hoped that following $\mathrm{N}-\mathrm{S}$ bond cleavage, the now electron rich amino species would form an imine 9 that would then undergo further reduction to afford 11. However, in the event the only isolable product was 12. Although the yield for this process was low, the isolated product indicated that $\mathrm{C} 11$ underwent reduction, presumably prior to $\mathrm{N}-\mathrm{S}$ bond cleavage.

Based on a recent report from Paquette [20], the dibromination of $\mathbf{5 a}$ and $\mathbf{5 b}$ was subsequently considered. We felt that bromination of the double bond would lead to further possibilities for subsequent functionalisation. This report indicated that the treatment of 5a with neat bromine gave the cis-1,2-dibromide 13a in quantitative yield. It was also reported that under more standard brominating conditions mixtures of diastereoisomeric 1,2-dibromides were formed. In our hands broadly similar results were encountered using chloroform or dichloromethane as reaction solvents (e.g. Entries 1-3). Furthermore, separation of the different diastereoisomers by column chromatography proved difficult. The unusual stereochemical outcome of this bromination process was carefully studied by a combination of NOE analysis, using the diagnostic $12 \mathrm{a}-\mathrm{CH}_{2}$ signal, and $\mathrm{X}$-ray crystallography which helped to substantiate the structures of the minor 1,2-trans-diastereoisomers 14a and 15a (see crystallographic data). Optimum conditions, forming 13a as the major diastereomer, were ultimately found (Scheme 4). Thus, addition of bromine to the compound in toluene at low temperature gave 13a in $75 \%$ isolated yield and high diastereoselectivity as observed by ${ }^{1} \mathrm{H}$ NMR spectroscopy of the crude reaction mixture (Entry 4).

In an attempt to further understand the mechanism of this bromination reaction, a bromo-methanolysis reaction was carried out (Entry 5). Interestingly, regio- and diastereoselective formation of the cis-16a was observed in good yield. When 13a was taken up in methanol no conversion into 16a, via an $\mathrm{S}_{\mathrm{N}} 1$-type process, was observed. The use of THF as solvent led to the formation of compound $\mathbf{1 7 a}$, albeit in low yield, in which a molecule of the solvent has been incorporated (Entry 6). For X-ray crystal structure of 13a see Figure 2.

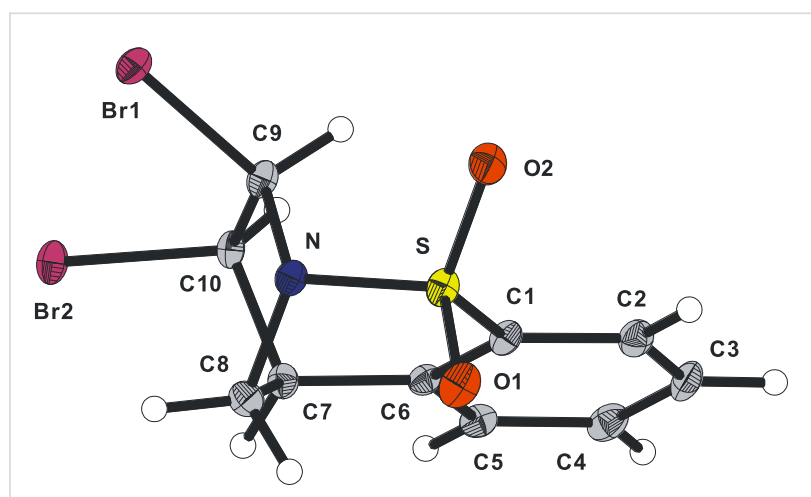

Figure 2: X-ray crystal structure of 13a (Diamond representation). 


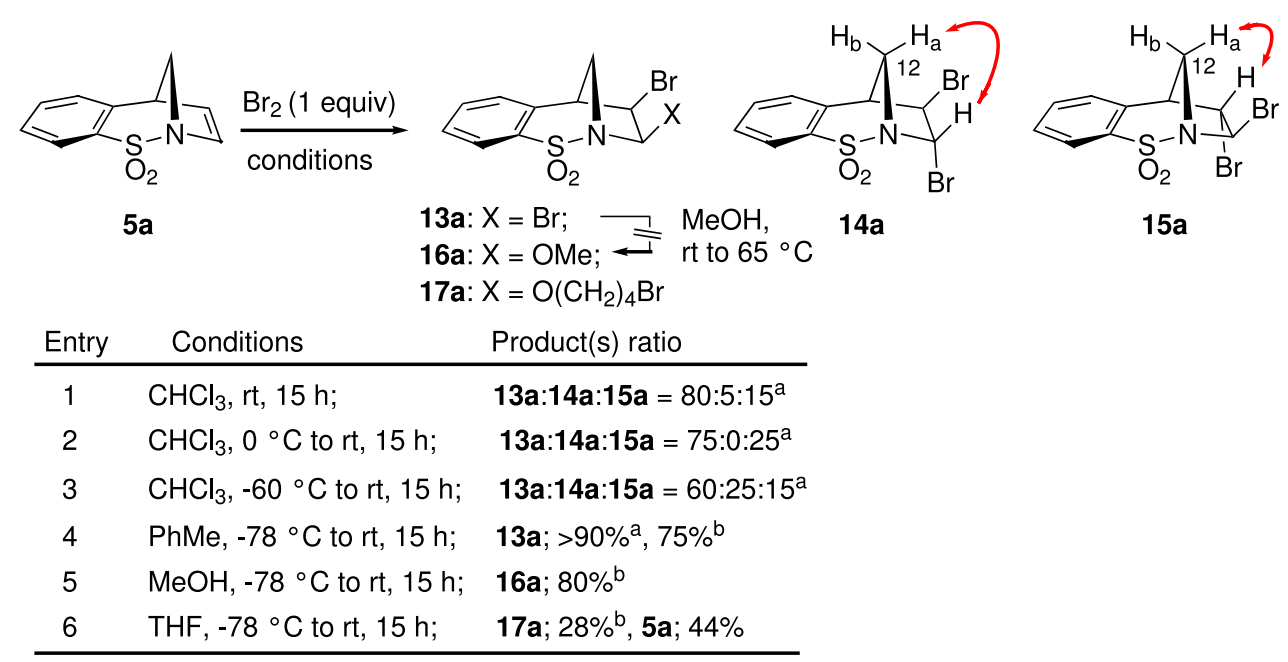

a Ratio calculated by ${ }^{1} \mathrm{H}$ NMR spectroscopy;

${ }^{\mathrm{b}}$ Isolated yields after chromatographic purification

Scheme 4: cis-Selective dibromination of 5a (NOE indicated by arrows).

The analogous functionalisation of alkene $\mathbf{5 b}$ was then considered. In toluene (Scheme 5, Entry 1), the optimal solvent for the cis-dibromination of $\mathbf{5 b}$, as hoped, selective formation of 13b was observed ( $>90 \%$ by ${ }^{1} \mathrm{H}$ NMR spectroscopy of the crude mixture). It should be noted that whilst the selectivity of this reaction is good, it did prove difficult to perform in a reproducible manner based on the limited solubility of $\mathbf{5 b}$ in toluene and competing benzyl bromide formation in some instances.

When the same reaction was conducted in chloroform, the formation of $\mathbf{1 8 b}$ as the major product ( $42 \%$ yield) was observed (Entry 2). The identity of this compound was determined by single crystal X-ray crystallography (Figure 3). Strik- ingly, none of this rearranged type of product was observed for 5a under identical conditions. The yield for this process was increased to $87 \%$ when an excess of $\mathrm{Br}_{2}$ (10 equiv) was employed. The bromo-methanolysis reaction, performed as described above, gave a mixture of compounds $16 \mathrm{~b}$ and $19 \mathrm{~b}$ in $58 \%$ and $37 \%$ yields, respectively (Entry 3 ). The structure of 19b was also confirmed by X-ray crystallography (see Figure 3 and crystallographic data).

Based on the results obtained we propose a mechanistic explanation illustrated in Scheme 6 to account for the products formed. It seems reasonable to speculate that the cis-1,2dibromide formation results from the slow reaction of the<smiles></smiles>

$5 b$

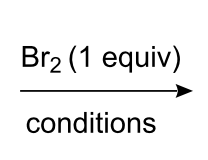

$\mathrm{MeO}$

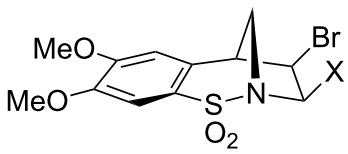

13b: $\mathrm{X}=\mathrm{Br}$;

16b: $X=O M e$

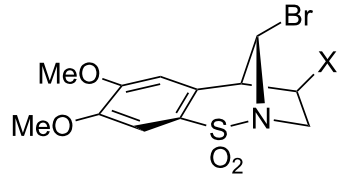

18b: $\mathrm{X}=\mathrm{Br}$;

19b: $X=O M e$

\begin{tabular}{ccl} 
Entry & Conditions & Product(s) \\
\hline 1 & $\mathrm{PhMe},-78{ }^{\circ} \mathrm{C}$ to rt, $15 \mathrm{~h} ;$ & $13 \mathrm{~b},>90 \%^{\mathrm{a}} ; 78 \%^{\mathrm{b}}$ \\
2 & $\mathrm{CHCl}_{3},-78{ }^{\circ} \mathrm{C}$ to rt, $15 \mathrm{~h} ;$ & $18 \mathrm{~b},>90 \%^{\mathrm{a}} ; 42 \%^{\mathrm{b}}(87 \%)^{\mathrm{c}}$ \\
3 & $\mathrm{MeOH},-78^{\circ} \mathrm{C}$ to rt, $15 \mathrm{~h} ;$ & $16 \mathrm{~b}, 58 \%^{\mathrm{b}} ; 19 \mathrm{~b}, 37 \%^{\mathrm{b}}$ \\
\hline
\end{tabular}

aRatio calculated by ${ }^{1} \mathrm{H}$ NMR spectroscopy;

bIsolated yields after chromatographic purification;

cIsolated yield when 10 equiv of $\mathrm{Br}_{2}$ were used. 


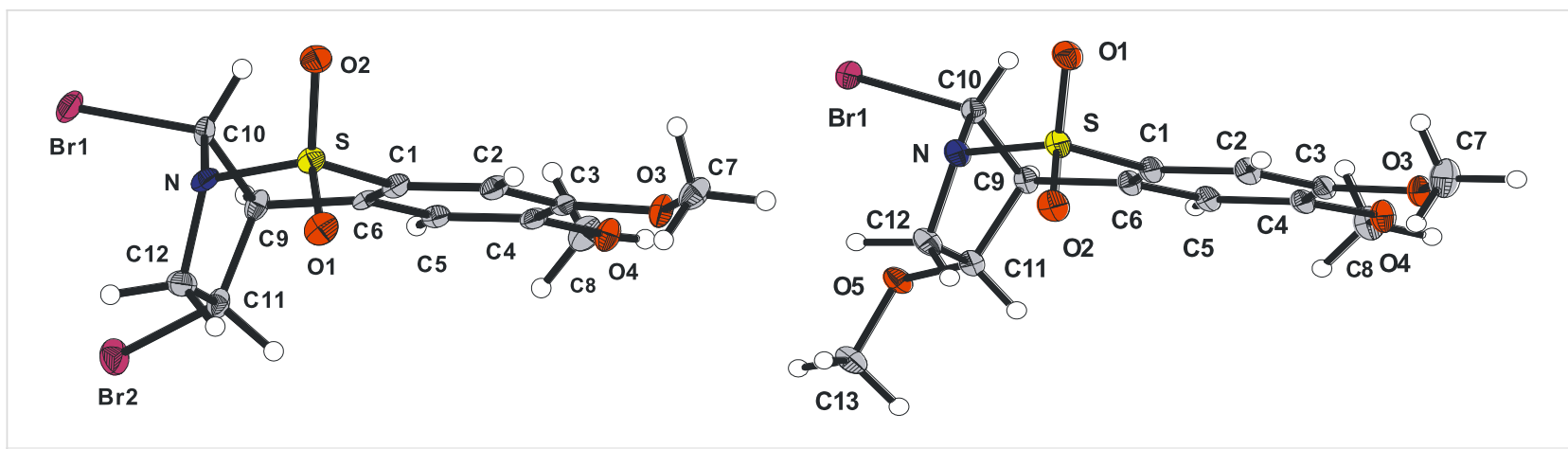

Figure 3: X-ray crystal structures of $18 \mathrm{~b}$ and $19 \mathrm{~b}$ (Diamond representations).

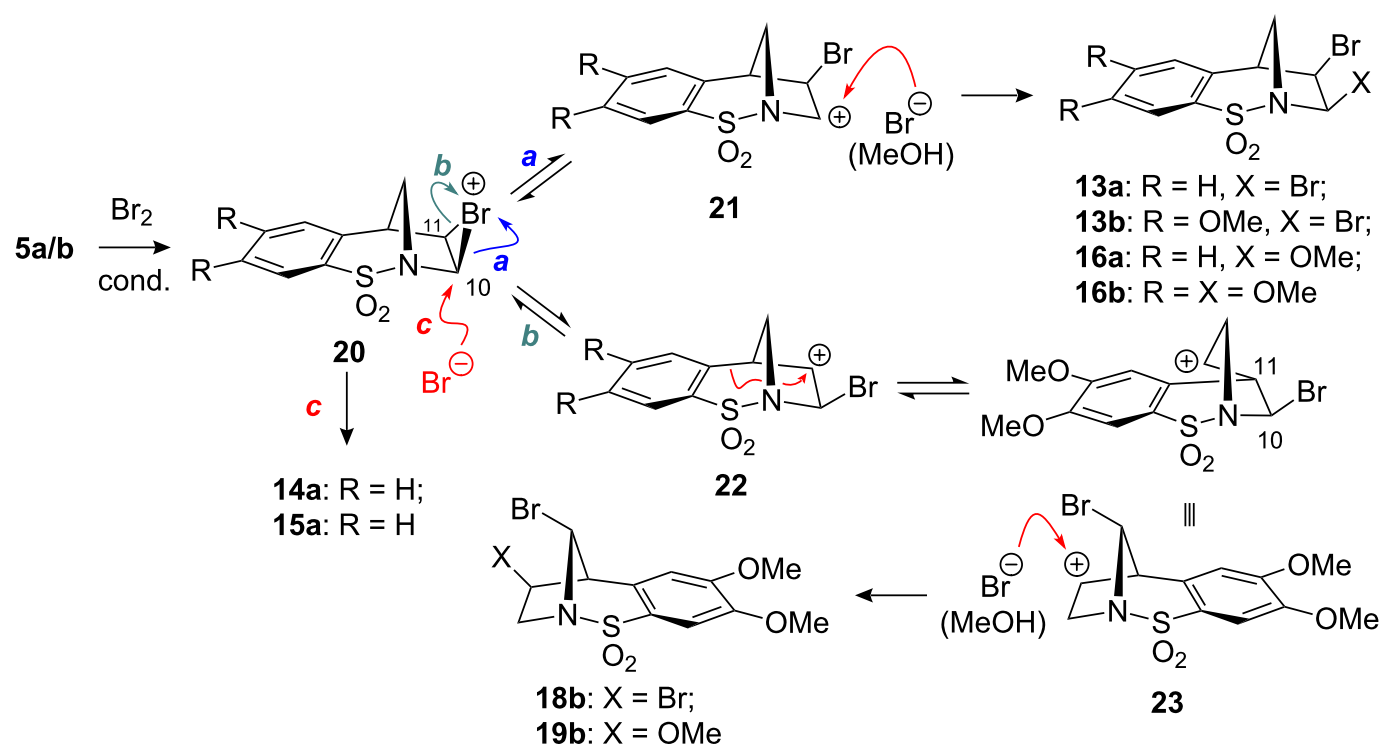

Scheme 6: Possible explanation for the products formed in the dibromination of $\mathbf{5 a}$ and $\mathbf{5 b}$.

bromonium ion $\mathbf{2 0}$ with bromide due to the blocking of the lower face by the aromatic ring (route c). Indeed, the epoxide 7a (Figure 1) may be considered a bromonium ion model and inspection of this representation demonstrates the pronounced fold of this structure. Consequently, since the $\mathrm{S}_{\mathrm{N}} 2$ process is retarded the bromide may then intercept either carbocation 21, or 22 in an $\mathrm{S}_{\mathrm{N}} 1$ sense, from the less hindered, top face, forming 13a and 13b. Using methanol as the solvent the cis-1,2-difunctionalised compounds $\mathbf{1 6 a}$ and $\mathbf{1 6} \mathbf{b}$ were formed regioselectively (none of the products resulting from methanolysis of $\mathbf{2 2}$ were detected). The regiochemical outcome of this process suggests that either the carbocation adjacent to nitrogen is energetically more stable, or that it is more reactive under these conditions. In relation to the $N$-sulfonyl group and its ability to stabilise an $\alpha$-carbocation, $N$-sulfonyl iminium ions have been implicated in many instances $[18,19,21]$. However, in this particular case, based on the conformation of the rigid bicyclic molecule, this mode of stabilisation is not feasible. An alterna- tive mechanism of stabilisation has been suggested in which one of the sulfonyl oxygen atoms may act as a Lewis base and in doing so stabilise the positive charge [22,23]. Inspection of the X-ray structure obtained for compounds $7 \mathbf{a}$ and $7 \mathbf{b}$ (not shown) indicates that this stabilisation mechanism may be possible based on the distance between the carbon atom of the epoxide and its closest sulfonyl oxygen atom (see Figure 1).

In the case of carbocation 22, the benzylic bond appears to be aligned with the empty p-orbital, consequently, when the aromatic ring is substituted with the $+\mathrm{M}$ methoxy substituents the results obtained indicate that a Wagner-Meerwein-type rearrangement occurs to generate carbocation 23. Depending on the conditions this species is then intercepted, again diastereoselectively, by bromide or methanol, affording $\mathbf{1 8 b}$ and $\mathbf{1 9 b}$, respectively. In the case of $\mathbf{5 b}$ in chloroform and methanol this carbocation rearrangement takes place faster than any nucleophilic interception of species $\mathbf{2 1}$ and 22. (A hydride shift from 
the bridging $\mathrm{CH}_{2}$ to carbocation 21 was also considered; however, based on the regioselective formation of compound 19b this mechanism was discounted.) The remarkable contrasting behaviour for compound $\mathbf{5 b}$ in chloroform and toluene appears to be explained based on the polarity of the respective solvents. Toluene with a low dielectric constant favours formation of $\mathbf{1 3 b}$ whereas the more polar chloroform facilitates the rearrangement chemistry via carbocation $\mathbf{2 2}$. This type of terpene-like carbocation rearrangement has been reported for molecules which might be considered related to our [2.2.1]-bicyclic systems and has been termed a molecular somersault [24].

Regioselective elimination of the cis-dibromides 13a and 13b with TBAF, according to Paquette's procedure [20], gave the vinyl bromides 24a and 24b in good yields, respectively (Scheme 7). Vinyl bromide 24a was then subjected to lithiation with $t$-BuLi, followed by a $\mathrm{CO}_{2}$ quench. The desired carboxylic acid recovered from this reaction was only formed in low yields possibly due to issues with competing directed ortho-lithiation [25]. Notwithstanding, this acid was transformed into the corresponding methyl ester $\mathbf{2 5}$ using a Steglich-type esterification. Alkenyl reduction of the $\alpha, \beta$-unsaturated ester under standard conditions gave the product of hydrogenation as an undetermined 3:1 mixture of diastereoisomers. The likely explanation for this mixture of products, based on the high levels of diastereoselectivity observed in the similar examples discussed herein, is that the initially formed product begins to undergo epimerisation in order to place the larger $\left(\mathrm{CO}_{2} \mathrm{Me}\right)$ substituent on the least hindered face. Consequently, the complete epimerisation of this material was investigated using $\mathrm{NaOMe}(1 \mathrm{M})$ based on a literature report [26]. Pleasingly, the hoped for process did indeed lead to the formation of one diastereomer of carboxylic acid 26, which was formed from the methyl ester on hydrolysis following work-up (see Figure 4 and crystallo- graphic data). Although the yields described during this sequence are low at this stage, the successful epimerisation observed demonstrates that this approach represents a stereocomplementary method to those described in Scheme 1 and Scheme 8.

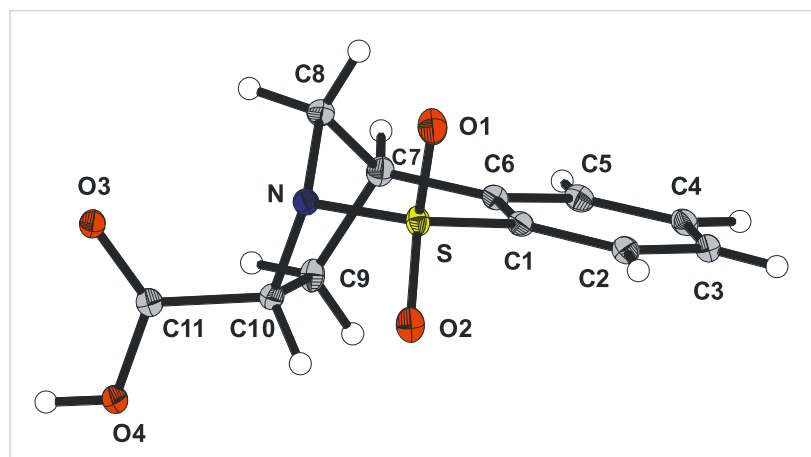

Figure 4: X-ray structure of 26 (Diamond representation).

With the lithiation chemistry described above proving inefficient, palladium chemistry was subsequently considered. The vinyl bromide 24a was reported to participate in Sonagashira alkynylation chemistry; however, yields of the resultant enyne were low [20]. Therefore, we decided to investigate Suzuki-Miyaura cross-coupling reaction as a means of incorporating alternative structural features into our masked pyrrolidine ring. Under standard conditions, the reactivity of a series of commercially available aryl and alkenyl boronic acids with 24a was investigated. Pleasingly, it was found that in the case of the aryl boronic acids, good yields of the resultant styryl adducts 27-30 were observed. It was found that employment of the boronic acids in excess (approximately 5 equiv) in conjunction with base work-up gave the desired products in good yields with no starting material $\mathbf{2 4 a}$, or the product of bromine-hydrogen exchange 5a. Unfortunately, under identical

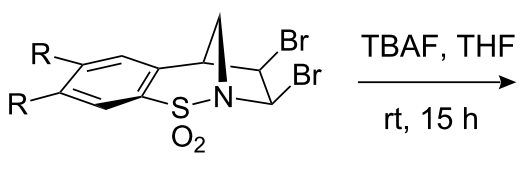

13a: $\mathrm{R}=\mathrm{H}$;

13b: $R=O M e$

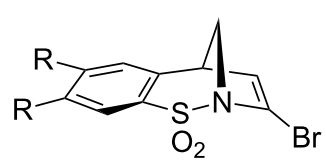

24a: $R=H, 80 \%$;

24b: $\mathrm{R}=\mathrm{OMe}, 67 \%$

\begin{abstract}
(i) $t$-BuLi ( 3 equiv), $-78{ }^{\circ} \mathrm{C}, \mathrm{Et}_{2} \mathrm{O}, 5 \mathrm{~min}$ $24 a$ (ii) $\mathrm{CO}_{2}, 15 \mathrm{~min}$ (iii) EDCl, cat. DMAP, $\mathrm{MeOH}-\mathrm{CH}_{2} \mathrm{Cl}_{2}, 23 \%$
\end{abstract}

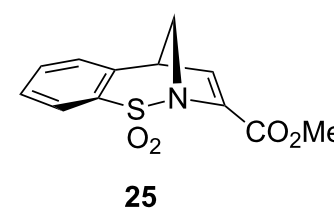




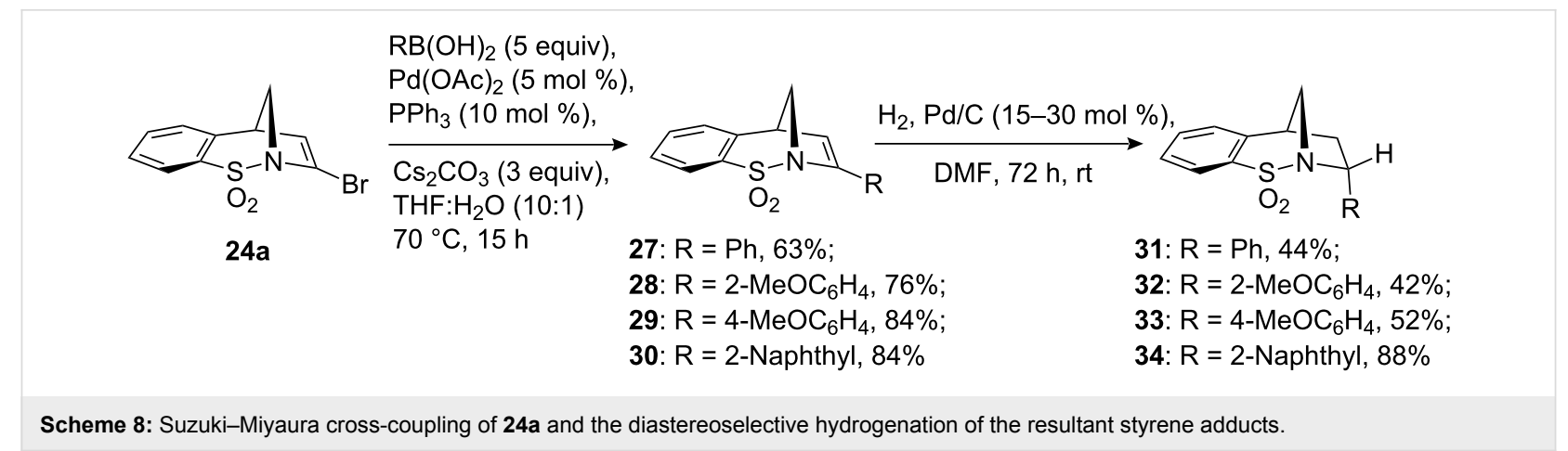

conditions no cross-coupled products were obtained following several attempts using $Z$-crotyl boronic acid and vinyl boronic acid.

Hydrogenation of the trisubstituted alkene in compounds 27-30 was carried out in DMF due to the poor solubility of these compounds in more standard solvents. These reactions also proved rather slow. Nevertheless, after $72 \mathrm{~h}$ under a hydrogen atmosphere in the presence of $\mathrm{Pd} / \mathrm{C}$, moderate to good yields of compounds 31-34 were achieved. As predicted, the addition of hydrogen took place in a diastereoselective manner and the adducts were formed as single diastereoisomers. This sense of diastereoselectivity was confirmed by a series of NOE experiments and the single X-ray crystal structure obtained for compound 31 (see Figure 5 and crystallographic data). Poor conversion was observed when the one-pot reductive-palladium method, analogous to that described in Scheme 2, was attempted.

The double reduction of compounds 31-34 was next considered. Cleavage of both the S-N and S-C bonds would result in the formation of a series of cis-diaryl-substituted pyrrolidine ring containing compounds. Consequently, treatment of each compound under the currently optimal conditions (lithium in liquid ammonia at $-78^{\circ} \mathrm{C}$ ) gave the products of reduction which were converted into the corresponding tosyl derivatives to aid characterisation and purification (Scheme 9).

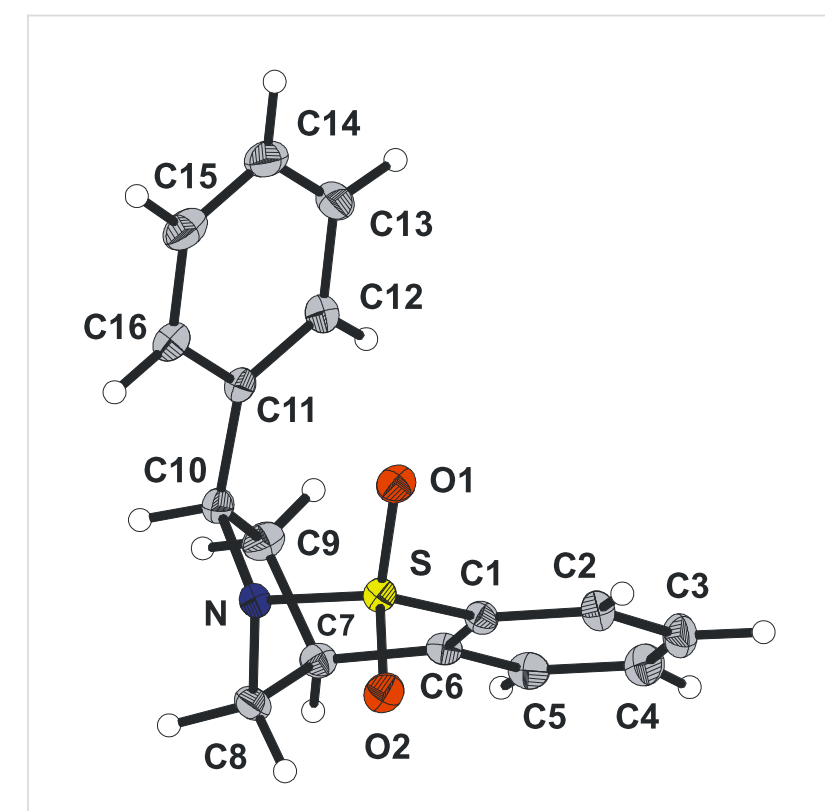

Figure 5: X-ray crystal structure of $\mathbf{3 1}$ (Diamond representation).

The successful double reduction of compounds 31-33 was observed in moderate/low yields. In the case of compound 31, a significant amount of the product $\mathbf{3 9}$ of benzylic cleavage was also detected. This type of product was not observed for the more electron rich, methoxy-containing substituents, presumably since the Birch-type radical anionic intermediate, which

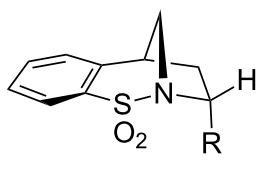

31: $\mathrm{R}=\mathrm{Ph}$;

32: $\mathrm{R}=2-\mathrm{MeOC}_{6} \mathrm{H}_{4}$

33: $\mathrm{R}=4-\mathrm{MeOC}_{6} \mathrm{H}_{4}$;

34: $\mathrm{R}=2$-Naphthyl (i) $\mathrm{Li}$ ( 5 equiv),

$\mathrm{NH}_{3},-78^{\circ} \mathrm{C}$

(ii) $\mathrm{NH}_{4} \mathrm{Cl}$

(iii) $\mathrm{TsCl}, \mathrm{CH}_{2} \mathrm{Cl}_{2}$,

$\mathrm{Et}_{3} \mathrm{~N}, 3 \mathrm{~h}, \mathrm{O}^{\circ} \mathrm{C}$ to rt<smiles>[R]C1CC([PH])CN1S</smiles>

35: $\mathrm{R}=\mathrm{Ph}, 20 \%$;

36: $\mathrm{R}=2-\mathrm{MeOC}_{6} \mathrm{H}_{4}, 24 \%$

37: $\mathrm{R}=4-\mathrm{MeOC}_{6} \mathrm{H}_{4}, 40 \%$;

38: $\mathrm{R}=2$-Naphthyl, $0 \%$<smiles>[R]CCC(C[NH-])c1ccccc1</smiles>

9: $\mathrm{R}=\mathrm{Ph}, 48 \%$<smiles>CN1C[C@@H](c2ccccc2)C[C@H]1C1=CCc2ccccc2C1</smiles>

40 
enables the elimination of the amino group, is disfavoured in this instance. In the case of compound 34, trace amount of the hoped for product $\mathbf{3 8}$ was detected. However, in this case the major product $\mathbf{4 0}$ stems from the partial reduction of the naphthyl ring in addition to cleavage of the sulfonyl tether.

\section{Conclusion}

In summary, the work described demonstrates that we were able to utilise the functionalisation of bicyclic sulfonamide $\mathbf{5 a}$ featuring a Suzuki coupling and a diastereoselective hydrogenation to construct $c i s$-2,4-diarylpyrrolidines in a diastereoselective manner. The epimerisation reaction which led to the formation of carboxylic acid $\mathbf{2 6}$ demonstrates, in principle, how the trans-2,4-substituted series might also be accessible. The cis-diastereoselective dibromination of the bridgehead sultams $\mathbf{5 a}$ and $\mathbf{5 b}$ was also studied from a mechanistic perspective and related to this an unusual molecular somersault was uncovered, the occurrence of which was dependent on the electronic nature of the aryl motif and of the reaction solvent.

\section{Experimental}

Representative experimental procedures are shown for compounds 7a, 13a, 18b, 24a, 27, 31, 35, 39. For full experimental details see accompanying Supporting Information.

$( \pm)-(1 S, 10 R, 11 R)$-Epoxy-8-thia-9-azatricyclo[7.2.1.0 $\left.{ }^{2,7}\right]-$ dodeca-2(7),3,5-triene-8,8-dioxide (7a): To a solution of alkene 5 a (252 mg, $1.22 \mathrm{mmol}, 1$ equiv) in $\mathrm{CH}_{2} \mathrm{Cl}_{2}(50 \mathrm{~mL})$ at $0{ }^{\circ} \mathrm{C}, 70 \%$ (w/w) $m$-CPBA (1.68 g, $6.82 \mathrm{mmol}, 5.5$ equiv) was added. The reaction mixture was stirred for $72 \mathrm{~h}$ during which time room temperature was reached. The reaction was quenched with a saturated $\mathrm{Na}_{2} \mathrm{SO}_{3}$ solution $(15 \mathrm{~mL})$ which was basified after $0.5 \mathrm{~h}$ with a saturated $\mathrm{NaHCO}_{3}$ solution $(15 \mathrm{~mL}) . \mathrm{H}_{2} \mathrm{O}(10$ $\mathrm{mL}$ ) was added and the aqueous layer was then extracted with $\mathrm{CH}_{2} \mathrm{Cl}_{2}(2 \times 20 \mathrm{~mL})$. The combined organic extracts were dried over $\mathrm{MgSO}_{4}$. Filtration followed by solvent removal in vacuo afforded the crude product, which was purified by flash column chromatography (c-Hex-EtOAc; 5:1) affording 7a (179 mg, $66 \%)$ as a colourless solid. Recrystallisation from EtOAc gave crystals suitable for X-ray crystallographic analysis. mp $164-165{ }^{\circ} \mathrm{C}\left(\right.$ EtOAc); $R_{f}=0.45$ (c-Hex-EtOAc; $\left.1: 1\right) ;{ }^{1} \mathrm{H}$ NMR $\left(300 \mathrm{MHz}, \mathrm{CDCl}_{3}\right)$ : $\delta 3.27(\mathrm{~d}, J=4.0 \mathrm{~Hz}, 1 \mathrm{H}, 1-\mathrm{CH}), 3.35$ (dd, $\left.J=4.0,12.5 \mathrm{~Hz}, 1 \mathrm{H}, 1 \mathrm{H}, 12 \mathrm{a}-\mathrm{CH}_{2}\right), 3.65$ (s, 1H, 11-CH), 3.92 $\left(\mathrm{d}, J=12.5 \mathrm{~Hz}, 1 \mathrm{H}, 12 \mathrm{~b}-\mathrm{CH}_{2}\right), 5.03(\mathrm{~s}, 1 \mathrm{H}, 10-\mathrm{CH}), 7.19$ (d, $J=$ 6.5 Hz, 1H, ArH), 7.40-7.47 (m, 2H, ArH), 7.67-7.80 (m, 1H, $\mathrm{ArH}) ;{ }^{13} \mathrm{C}$ NMR (100 MHz, $\left.\mathrm{CDCl}_{3}\right): \delta 39.5(\mathrm{CH}), 49.4\left(\mathrm{CH}_{2}\right)$, $57.8(\mathrm{CH}), 65.4(\mathrm{CH}), 127.0(\mathrm{CH}), 127.7(\mathrm{CH}), 130.1(\mathrm{CH})$, $132.5(\mathrm{CH}), 135.3(\mathrm{C}), 136.3(\mathrm{C}) ; v_{\max }\left(\mathrm{CH}_{2} \mathrm{Cl}_{2} / \mathrm{cm}^{-1}\right)(\mathrm{KCl})$ 3067, 3037, 1472, 1381, 1335, 1246, 1205, 1170, 1061, 1007, $935,916,855,811,792,767,750,715,609 ; \mathrm{m} / \mathrm{z}(\mathrm{ES})$ required $224.0379\left(\mathrm{MH}^{+}, 100 \%\right)$; found 224.0381 (-1.1 ppm); Anal.
Calcd for $\mathrm{C}_{10} \mathrm{H}_{9} \mathrm{NO}_{3} \mathrm{~S}$ : C, 53.80; H, 4.06; N, 6.27. Found: C, 53.63 ; H, 4.04; N, 6.06 .

( \pm )-(1S,10R,11R)-10,11-Dibromo-8-thia-9-azatricyclo[7.2.1.0 ${ }^{\mathbf{2}, 7}$ ]dodeca-2(7),3,5-triene-8,8-dioxide (13a) [20]: To a solution of alkene 5a (50 mg, $0.24 \mathrm{mmol}, 1.2$ equiv) in $\mathrm{PhMe}$ $(10 \mathrm{~mL})$ at $-78{ }^{\circ} \mathrm{C}, \mathrm{Br}_{2}(0.01 \mathrm{~mL}, 0.20 \mathrm{mmol}, 1$ equiv) was added. The reaction mixture was stirred for $15 \mathrm{~h}$ during which time, room temperature was reached. The reaction was quenched with a saturated solution of $\mathrm{Na}_{2} \mathrm{SO}_{3}(10 \mathrm{~mL})$ and $\mathrm{H}_{2} \mathrm{O}(10 \mathrm{~mL})$ was added. The resultant aqueous layer was then further extracted with $\mathrm{CH}_{2} \mathrm{Cl}_{2}(2 \times 10 \mathrm{~mL})$ and the combined organic extracts were dried over $\mathrm{MgSO}_{4}$. Filtration followed by solvent removal in vacuo afforded the crude product, which was purified by flash column chromatography (c-Hex-EtOAc; 9:1) affording 13a (55 mg, 75\%) as a colourless solid. mp 174-176 ${ }^{\circ} \mathrm{C}$ (EtOAc), lit. $185-188^{\circ} \mathrm{C}[20] ; R_{f}=0.6$ (c-Hex-EtOAc; $1: 1$ ); ${ }^{1} \mathrm{H}$ NMR (400 MHz, $\left.\mathrm{CDCl}_{3}\right): \delta 3.66(\mathrm{~s}, 1 \mathrm{H}, 1-\mathrm{CH}), 4.10(\mathrm{~d}, J=$ $\left.13.0 \mathrm{~Hz}, 1 \mathrm{H}, 12 \mathrm{a}-\mathrm{CH}_{2}\right), 4.30\left(\mathrm{~d}, J=13.0 \mathrm{~Hz}, 1 \mathrm{H}, 12 \mathrm{~b}-\mathrm{CH}_{2}\right)$, $4.66(\mathrm{~d}, J=6.0 \mathrm{~Hz}, 1 \mathrm{H}, 11-\mathrm{CH}), 6.47(\mathrm{~d}, J=6.0 \mathrm{~Hz}, 1 \mathrm{H}$, $10-\mathrm{CH}), 7.35(\mathrm{~d}, J=7.0 \mathrm{~Hz}, 1 \mathrm{H}, \operatorname{ArH}), 7.50-7.60(\mathrm{~m}, 2 \mathrm{H}$, $\mathrm{ArH}), 7.81(\mathrm{~d}, J=7.0 \mathrm{~Hz}, 1 \mathrm{H}, \mathrm{ArH}) ;{ }^{13} \mathrm{C} \mathrm{NMR}(100 \mathrm{MHz}$, $\left.\mathrm{CDCl}_{3}\right): \delta 52.3(\mathrm{CH}), 52.8\left(\mathrm{CH}_{2}\right), 57.8(\mathrm{CH}), 67.6(\mathrm{CH}), 126.6$ $(\mathrm{CH}), 126.7(\mathrm{CH}), 130.5(\mathrm{CH}), 133.7(\mathrm{CH}), 134.9(\mathrm{C}), 135.9$ (C); $v_{\max }\left(\mathrm{CH}_{2} \mathrm{Cl}_{2} / \mathrm{cm}^{-1}\right)(\mathrm{NaCl}) 3010,2977,1446,1344,1324$, 1300, 1263, 1234, 1206, 1162, 1077; Anal. Calcd for $\mathrm{C}_{10} \mathrm{H}_{9} \mathrm{Br}_{2} \mathrm{NO}_{2} \mathrm{~S}: \mathrm{C}, 32.70 ; \mathrm{H}, 2.45 ; \mathrm{N}, 3.89 ; \mathrm{Br}, 43.60$. Found: C, 32.66; H, 2.31; N, 3.41; Br, 43.27.

( \pm )-(1R,11R,12S)-11,12-Dibromo-4,5-dimethoxy-8-thia-9azatricyclo[7.2.1.0 $\left.{ }^{2,7}\right]$ dodeca-2(7),3,5-triene-8,8-dioxide (18b): To a solution of alkene $\mathbf{5 b}$ ( $75 \mathrm{mg}, 0.28 \mathrm{mmol}, 1$ equiv) in $\mathrm{CHCl}_{3}(10 \mathrm{~mL})$ at $-78{ }^{\circ} \mathrm{C}, \mathrm{Br}_{2}(0.15 \mathrm{~mL}, 2.80 \mathrm{mmol}, 10$ equiv) was added. The reaction mixture was stirred for $15 \mathrm{~h}$ during which time, room temperature was reached. The reaction was quenched with a saturated solution of $\mathrm{Na}_{2} \mathrm{SO}_{3}(20 \mathrm{~mL})$ and $\mathrm{H}_{2} \mathrm{O}(20 \mathrm{~mL})$ was added. The aqueous layer was then further extracted with $\mathrm{CH}_{2} \mathrm{Cl}_{2}(2 \times 20 \mathrm{~mL})$ and the combined organic extracts were dried over $\mathrm{MgSO}_{4}$. Filtration followed by solvent removal in vacuo afforded the crude product, which was purified by flash column chromatography (c-Hex-EtOAc; $5: 1$ ) affording 18b (104 mg, 87\%) as a colourless solid. Recrystallisation from EtOAc gave crystals suitable for X-ray crystallographic analysis. $\mathrm{mp} 225^{\circ} \mathrm{C}\left(\right.$ EtOAc); $R_{f}=0.6$ (c-Hex-EtOAc; $1: 1) ;{ }^{1} \mathrm{H}$ NMR (500 MHz, $\left.\mathrm{CDCl}_{3}\right): \delta 3.86(\mathrm{~s}, 1 \mathrm{H}, 1-\mathrm{CH}), 3.91$ (s, $\left.3 \mathrm{H}, \mathrm{CH}_{3}\right), 3.96\left(\mathrm{~s}, 3 \mathrm{H}, \mathrm{CH}_{3}\right), 4.13(\mathrm{dd}, J=5.0,8.0 \mathrm{~Hz}, 1 \mathrm{H}$, $11-\mathrm{CH}), 4.20\left(\mathrm{dd}, J=5.0,15.0 \mathrm{~Hz}, 1 \mathrm{H}, 10 \mathrm{a}-\mathrm{CH}_{2}\right), 4.60$ (dd, $J=$ 8.0, $\left.15.0 \mathrm{~Hz}, 1 \mathrm{H}, 10 \mathrm{~b}-\mathrm{CH}_{2}\right), 6.32(\mathrm{~s}, 1 \mathrm{H}, 12-\mathrm{CH}), 6.70(\mathrm{~s}, 1 \mathrm{H}$, $\mathrm{ArH}), 7.19$ (s, 1H, ArH); ${ }^{13} \mathrm{C}$ NMR (125 MHz, $\left.\mathrm{CDCl}_{3}\right): \delta 44.0$ $(\mathrm{CH}), 56.3(\mathrm{CH}), 56.4\left(\mathrm{CH}_{3}\right), 58.5\left(\mathrm{CH}_{3}\right), 58.9(\mathrm{CH}), 64.5$ $\left(\mathrm{CH}_{2}\right), 107.8(\mathrm{CH}), 108.5(\mathrm{CH}), 126.3(\mathrm{C}), 130.2(\mathrm{C}), 150.4$ 
(C), $153.2(\mathrm{C}) ; v_{\max }\left(\mathrm{CH}_{2} \mathrm{Cl}_{2} / \mathrm{cm}^{-1}\right)(\mathrm{NaCl}) 3096,2975,1593$, 1444, 1326, 1260, 1203, 1164, 1044; Anal. Calcd for $\mathrm{C}_{12} \mathrm{H}_{13} \mathrm{Br}_{2} \mathrm{NO}_{4} \mathrm{~S}$ : C, 33.75; H, 3.07; N, 3.28. Found: C, 33.69; H, 2.99; N, 3.17.

10-Bromo-8-thia-9-azatricyclo[7.2.1.0 $\left.{ }^{2,7}\right]$ dodeca-2,4,6,10tetraene-8,8-dioxide (24a) [20]: Compound 13a (1.04 g, 2.83 mmol, 1 equiv) in THF $(15 \mathrm{~mL})$ was treated with a $1 \mathrm{M}$ solution of TBAF in THF (20 mL, $20.00 \mathrm{mmol}, 7$ equiv) for $15 \mathrm{~h}$. The solvent was removed in vacuo and $\mathrm{CH}_{2} \mathrm{Cl}_{2}$ was added (30 $\mathrm{mL})$. The organic layer was washed with a saturated solution of $\mathrm{NaHCO}_{3}(30 \mathrm{~mL})$, the aqueous phase further extracted with $\mathrm{CH}_{2} \mathrm{Cl}_{2}(30 \mathrm{~mL})$ and the combined organic layers were dried over $\mathrm{MgSO}_{4}$. Filtration followed by solvent removal in vacuo afforded the crude product, which was purified by flash column chromatography (c-Hex-EtOAc; 1:1) affording 24a (700 mg, $86 \%)$ as a colourless solid. mp $188-192{ }^{\circ} \mathrm{C}\left(\mathrm{CH}_{2} \mathrm{Cl}_{2}\right) ; R_{f}=0.3$ (c-Hex-EtOAc; $1: 1) ;{ }^{1} \mathrm{H}$ NMR (400 MHz, $\mathrm{CDCl}_{3}$ ): $\delta 3.29$ (t, $J$ $=4.0 \mathrm{~Hz}, 1 \mathrm{H}, \mathrm{CH}), 4.37\left(\mathrm{dd}, J=4.0,12.0 \mathrm{~Hz}, 1 \mathrm{H}, 12 \mathrm{a}-\mathrm{CH}_{2}\right)$, $4.59\left(\mathrm{~d}, J=12.0 \mathrm{~Hz}, 1 \mathrm{H}, 1 \mathrm{H}, 12 \mathrm{~b}-\mathrm{CH}_{2}\right), 6.68(\mathrm{~d}, J=4.0 \mathrm{~Hz}$, $1 \mathrm{H}, 11-\mathrm{CH}), 7.12(\mathrm{~d}, J=7.5 \mathrm{~Hz}, 1 \mathrm{H}, \mathrm{ArH}), 7.42(\mathrm{t}, J=7.5 \mathrm{~Hz}$, $1 \mathrm{H}, \operatorname{ArH}), 7.50$ (t, $J=7.5 \mathrm{~Hz}, 1 \mathrm{H}, \operatorname{ArH}), 7.77(\mathrm{~d}, J=7.5 \mathrm{~Hz}$, $1 \mathrm{H}, \mathrm{ArH}) ;{ }^{13} \mathrm{C} \mathrm{NMR}\left(100 \mathrm{MHz}, \mathrm{CDCl}_{3}\right): \delta 43.9(\mathrm{CH}), 65.5$ $\left(\mathrm{CH}_{2}\right), 125.0(\mathrm{C}), 125.4(\mathrm{CH}), 127.4(\mathrm{CH}), 130.2(\mathrm{CH}), 132.1$ $(\mathrm{CH}), 134.5(\mathrm{C}), 135.9(\mathrm{CH}), 139.3(\mathrm{C}) ; v_{\max }\left(\mathrm{CH}_{2} \mathrm{Cl}_{2} / \mathrm{cm}^{-1}\right)$ (NaCl) 3102, 2924, 1591, 1452, 1338, 1168, 1054, 925, 866, $749 ; \mathrm{m} / \mathrm{z}$ (ES) required $285.9549\left(\mathrm{MH}^{+}\left(\mathrm{Br}^{79}\right), 100 \%\right)$; found 285.9537 (+4.1 ppm); Anal. Calcd for $\mathrm{C}_{10} \mathrm{H}_{8} \mathrm{BrNO}_{2} \mathrm{~S}$ : C, 41.96; H, 2.80; N, 4.90; Found: C, 41.97; H, 2.77; N, 4.71.

10-Phenyl-8-thia-9-azatricyclo[7.2.1.0 $\left.{ }^{2,7}\right]$ dodeca-2,4,6,10tetraene-8,8-dioxide (27): Under $\mathrm{N}_{2}$, a mixture of the compound 24a (500 mg, $1.75 \mathrm{mmol}, 1$ equiv), phenylboronic acid (1.073 g, $8.80 \mathrm{mmol}, 5$ equiv), $\mathrm{Pd}(\mathrm{OAc})_{2}(20 \mathrm{mg}, 0.09$ mmol, $5 \mathrm{~mol} \%$ ), $\mathrm{PPh}_{3}$ (47 mg, $0.18 \mathrm{mmol}, 10 \mathrm{~mol} \%$ ) and $\mathrm{Cs}_{2} \mathrm{CO}_{3}(1.714 \mathrm{~g}, 5.26 \mathrm{mmol}, 3$ equiv) in a mixture of THF: $\mathrm{H}_{2} \mathrm{O}(10: 1)(25 \mathrm{~mL})$ was heated to reflux for $15 \mathrm{~h}$. On cooling $\mathrm{Et}_{2} \mathrm{O}(20 \mathrm{~mL})$ and $\mathrm{H}_{2} \mathrm{O}(20 \mathrm{~mL})$ were added and the resultant aqueous layer was further extracted with $\mathrm{Et}_{2} \mathrm{O}(2 \times 20$ $\mathrm{mL}$ ) and the combined organic extracts were washed with a $2 \mathrm{M}$ $\mathrm{NaOH}$ solution $(20 \mathrm{~mL})$ and dried over $\mathrm{MgSO}_{4}$. Filtration followed by solvent removal under reduced pressure gave the crude product, which was purified by flash column chromatography (c-Hex-EtOAc; 5:1) affording 27 (314 mg, 63\%) as a colourless solid. mp $120-122{ }^{\circ} \mathrm{C}$ (EtOAc); $R_{f}=0.55$ (c-Hex-EtOAc; $1: 1) ;{ }^{1} \mathrm{H}$ NMR $\left(400 \mathrm{MHz}, \mathrm{CDCl}_{3}\right): \delta 3.44$ (t, $J$ $=4.0 \mathrm{~Hz}, 1 \mathrm{H}, \mathrm{CH}), 4.27\left(\mathrm{dd}, J=4.0,12.0 \mathrm{~Hz}, 1 \mathrm{H}, \mathrm{CH}_{2}\right), 4.70$ $\left(\mathrm{d}, J=12.0 \mathrm{~Hz}, 1 \mathrm{H}, \mathrm{CH}_{2}\right), 6.82(\mathrm{~d}, J=4.0 \mathrm{~Hz}, 1 \mathrm{H}, \mathrm{CH}), 7.17$ (d, $J=7.5 \mathrm{~Hz}, 1 \mathrm{H}, \mathrm{ArH}), 7.31-7.39$ (m, 3H, ArH), 7.40-7.47 (m, 2H, ArH), 7.69-7.71 (m, 3H, ArH); ${ }^{13} \mathrm{C}$ NMR (100 MHz, $\left.\mathrm{CDCl}_{3}\right): \delta 43.3(\mathrm{CH}), 64.3\left(\mathrm{CH}_{2}\right), 110.0(\mathrm{C}), 125.3(\mathrm{CH}), 126.6$
$(\mathrm{CH}), 127.1(\mathrm{CH}), 127.3(\mathrm{CH}), 128.3(\mathrm{CH}), 129.2(\mathrm{CH}), 129.7$ $(\mathrm{CH}), 131.7(\mathrm{CH}), 134.7$ (C), 140.8 (C), 147.0 (C); v $v_{\max }$ $\left(\mathrm{CH}_{2} \mathrm{Cl}_{2} / \mathrm{cm}^{-1}\right)(\mathrm{KCl}) 3063,1965,1592,1452,1327,1162$, 1029, 948; $\mathrm{m} / \mathrm{z}(\mathrm{ES})$ required $284.0733\left(\mathrm{MH}^{+}, 100 \%\right)$; found 284.0745 (-4.3 ppm); Anal. Calcd for $\mathrm{C}_{16} \mathrm{H}_{13} \mathrm{NO}_{2} \mathrm{~S}$ : C, 67.84; H, 4.59; N, 4.95. Found: C, 67.69; H, 4.65; N, 4.84.

$( \pm)-(1 S, 10 R)-10-P h e n y l-8-t h i a-9-a z a t r i c y c l o\left[7.2 .1 .0^{2,7}\right]-$ dodeca-2(7),3,5-triene-8,8-dioxide (31): 10\% (w/w) Pd/C (98 $\mathrm{mg}, 0.09 \mathrm{mmol}, 15 \mathrm{~mol} \%)$ was added to a solution of the alkene 27 (173 mg, $0.61 \mathrm{mmol}, 1$ equiv) in DMF (20 mL). The mixture was degassed before stirring under a hydrogen atmosphere (1 atm) at room temperature for $72 \mathrm{~h}$. Filtration through Celite $^{\circledR}$ and solvent removal in vacuo gave $32(77 \mathrm{mg}, 44 \%)$ as a colourless crystalline solid. mp $131-134{ }^{\circ} \mathrm{C}($ EtOAc $) ; R_{f}=0.5$ (c-Hex-EtOAc; 1:1); ${ }^{1} \mathrm{H}$ NMR (400 MHz, $\mathrm{CDCl}_{3}$ ): $\delta 2.36$ (ddd, $\left.J=2.0,7.5,13.0 \mathrm{~Hz}, 1 \mathrm{H}, \mathrm{CH}_{2}\right), 2.73$ (ddd, $J=7.5,10.0,13.0$ $\left.\mathrm{Hz}, 1 \mathrm{H}, \mathrm{CH}_{2}\right), 3.43(\mathrm{dd}, J=3.5,7.5 \mathrm{~Hz}, 1 \mathrm{H}, \mathrm{CH}), 3.56$ (dd, $J=$ $\left.3.5,12.5 \mathrm{~Hz}, 1 \mathrm{H}, \mathrm{CH}_{2}\right), 4.53\left(\mathrm{dd}, J=2.0,12.5 \mathrm{~Hz}, 1 \mathrm{H}, \mathrm{CH}_{2}\right)$, $5.05(\mathrm{dd}, J=7.5,10.0 \mathrm{~Hz}, 1 \mathrm{H}, \mathrm{CH}), 7.13-7.19$ (m, 2H, ArH), $7.22-7.29(\mathrm{~m}, 4 \mathrm{H}, \mathrm{ArH}), 7.36(\mathrm{dt}, J=1.0,7.0 \mathrm{~Hz}, 1 \mathrm{H}, \mathrm{ArH})$, $7.48(\mathrm{dt}, J=1.0,7.5 \mathrm{~Hz}, 1 \mathrm{H}, \mathrm{ArH}), 7.66(\mathrm{~d}, J=7.5 \mathrm{~Hz}, 1 \mathrm{H}, 1 \mathrm{H}$, $\mathrm{ArH}) ;{ }^{13} \mathrm{C} \mathrm{NMR}\left(100 \mathrm{MHz}, \mathrm{CDCl}_{3}\right): \delta 37.7\left(\mathrm{CH}_{2}\right), 40.1(\mathrm{CH})$, $59.1\left(\mathrm{CH}_{2}\right), 66.4(\mathrm{CH}), 125.8(\mathrm{CH}), 127.0(\mathrm{CH}), 127.9(\mathrm{CH})$, $128.2(\mathrm{CH}), 128.3(\mathrm{CH}), 129.8(\mathrm{CH}), 132.6(\mathrm{CH}), 135.1(\mathrm{C})$, 137.2 (C), $142.1(\mathrm{C}) ; v_{\max }\left(\mathrm{CH}_{2} \mathrm{Cl}_{2} / \mathrm{cm}^{-1}\right)(\mathrm{KCl}) 3042,2956$, 2342, 1954, 1876, 1596, 1452, 1324, 1163, 1087, 975; $\mathrm{m} / \mathrm{z}$ (ES) required $284.0894\left(\mathrm{MH}^{+}, 100 \%\right)$; found $284.0902(-2.7 \mathrm{ppm})$.

( \pm )-(2R,4S)-2,4-Diphenyl-1-(toluene-4-sulfonyl)pyrrolidine (35) and $N$-(2,4-diphenylbutyl)-4-methylbenzenesulfonamide (39): Under $\mathrm{N}_{2}$ at $-78{ }^{\circ} \mathrm{C}$ liquid $\mathrm{NH}_{3}$ (ca. $100 \mathrm{~mL}$ ) was treated with lithium wire (10 mg, $1.43 \mathrm{mmol}, 5$ equiv). This mixture was stirred for $1 \mathrm{~h}$ before a solution of $\mathbf{3 1}(80 \mathrm{mg}, 0.28$ mmol, 1 equiv) in THF $(5 \mathrm{~mL})$ was introduced dropwise. Stirring was continued at $-78{ }^{\circ} \mathrm{C}$ for $20 \mathrm{~min}$ before solid $\mathrm{NH}_{4} \mathrm{Cl}$ (ca. $5 \mathrm{~g}$ ) was added. The $\mathrm{NH}_{3}$ was allowed to evaporate and $\mathrm{Et}_{2} \mathrm{O}(25 \mathrm{~mL})$ and $\mathrm{H}_{2} \mathrm{O}(25 \mathrm{~mL})$ were added to the residue. The resultant aqueous layer was further extracted with $\mathrm{Et}_{2} \mathrm{O}(2 \times 25$ $\mathrm{mL}$ ) and the combined organic extracts were dried over $\mathrm{MgSO}_{4}$. Filtration, followed by solvent removal under reduced pressure, afforded a colourless oil. At $0{ }^{\circ} \mathrm{C}$ the crude material was treated with $\mathrm{Et}_{3} \mathrm{~N}$ (0.06 mL, $0.43 \mathrm{mmol}, 1.5$ equiv) and $\mathrm{TsCl}(53 \mathrm{mg}$, 0.28 mmol, 1 equiv) in $\mathrm{CH}_{2} \mathrm{Cl}_{2}(10 \mathrm{~mL})$. The mixture was stirred for $3 \mathrm{~h}$ during which time, room temperature was reached. $\mathrm{CH}_{2} \mathrm{Cl}_{2}(20 \mathrm{~mL})$ and $\mathrm{H}_{2} \mathrm{O}(20 \mathrm{~mL})$ were added and the resultant aqueous layer was further extracted with $\mathrm{CH}_{2} \mathrm{Cl}_{2}(2 \times$ $20 \mathrm{~mL}$ ). The combined organic extracts were dried over $\mathrm{MgSO}_{4}$, which was removed by filtration. The solvent was removed under reduced pressure and purification of the residue by flash column chromatography (c-Hex-EtOAc; 4:1) gave 
initially $35(21 \mathrm{mg}, 20 \%)$ as a colourless oil. $R_{f}=0.45$ (c-Hex-EtOAc; 3:1); ${ }^{1} \mathrm{H}$ NMR (400 MHz, $\mathrm{CDCl}_{3}$ ): $\delta 2.05$ (ddd, app. dt, $\left.J=10.0,12.5 \mathrm{~Hz}, 1 \mathrm{H}, \mathrm{CH}_{2}\right), 2.43\left(\mathrm{~s}, 3 \mathrm{H}, \mathrm{CH}_{3}\right)$, 2.63-2.72 (m, 1H, $\left.\mathrm{CH}_{2}\right), 2.90-3.02(\mathrm{~m}, 1 \mathrm{H}, \mathrm{CH}), 3.51(\mathrm{t}, J=$ $\left.11.0 \mathrm{~Hz}, 1 \mathrm{H}, \mathrm{CH}_{2}\right), 4.16$ (ddd, $J=1.0,7.0,11.0 \mathrm{~Hz}, 1 \mathrm{H}, \mathrm{CH}_{2}$ ), $4.82(\mathrm{dd}, J=7.0,10.0 \mathrm{~Hz}, 1 \mathrm{H}, \mathrm{CH}), 7.12(\mathrm{~d}, J=7.0 \mathrm{~Hz}, 2 \mathrm{H}$, ArH), 7.20-7.36 (m, 10H, ArH), 7.63 (d, $J=8.0 \mathrm{~Hz}, 2 \mathrm{H}, \mathrm{ArH})$; ${ }^{13} \mathrm{C}$ NMR $\left(100 \mathrm{MHz}, \mathrm{CDCl}_{3}\right): \delta 21.5\left(\mathrm{CH}_{3}\right), 43.7(\mathrm{CH}), 44.4$ $\left(\mathrm{CH}_{2}\right), 55.9\left(\mathrm{CH}_{2}\right), 64.5(\mathrm{CH}), 126.4(\mathrm{CH}), 127.0(\mathrm{CH}), 127.1$ $(\mathrm{CH}), 127.3(\mathrm{CH}), 127.4(\mathrm{CH}), 128.4(\mathrm{CH}), 128.7(\mathrm{CH}), 129.6$ $(\mathrm{CH}), 135.7$ (C), 139.0 (C), 142.5 (C), 143.3 (C); v $\max$ $\left(\mathrm{CH}_{2} \mathrm{Cl}_{2} / \mathrm{cm}^{-1}\right) 3059,2926,1599,1494,1432,1342,1289$, $1254,1158,1093,1027 ; \mathrm{m} / \mathrm{z}(\mathrm{ES})$ required $378.1535\left(\mathrm{MH}^{+}\right.$, $100 \%$ ); found $378.1528(+1.1 \mathrm{ppm})$. Further elution gave 39 (51 $\mathrm{mg}, 48 \%)$ as a colourless oil. $R_{f}=0.35(\mathrm{c}-\mathrm{Hex}-$ EtOAc; $3: 1) ;{ }^{1} \mathrm{H}$ $\operatorname{NMR}\left(300 \mathrm{MHz}, \mathrm{CDCl}_{3}\right): \delta 1.77-1.88\left(\mathrm{~m}, 1 \mathrm{H}, \mathrm{CH}_{2}\right), 1.90-2.00$ (m, 1H, $\left.\mathrm{CH}_{2}\right), 2.34-2.49\left(\mathrm{~m}, 5 \mathrm{H}, \mathrm{CH}_{3}, \mathrm{CH}_{2}\right), 2.63-2.72$ (m, $1 \mathrm{H}, \mathrm{CH}$ ), 3.00 (app. ddt, $J=4.5,9.0 \mathrm{~Hz}, 1 \mathrm{H}, \mathrm{CH}_{2}$ ), 3.27 (app. $\left.\mathrm{ddt}, J=5.5,8.0 \mathrm{~Hz}, 1 \mathrm{H}, \mathrm{CH}_{2}\right), 4.21(\mathrm{dd}, J=4.0,4.5 \mathrm{~Hz}, 1 \mathrm{H}$, NH), 7.01-7.06 (m, 4H, ArH), 7.13-7.35 (m, 8H, ArH), 7.62 (d, $J=8.0 \mathrm{~Hz}, 2 \mathrm{H}, \mathrm{ArH}) ;{ }^{13} \mathrm{C} \mathrm{NMR}\left(100 \mathrm{MHz}, \mathrm{CDCl}_{3}\right): \delta 21.5$ $\left(\mathrm{CH}_{3}\right), 33.1\left(\mathrm{CH}_{2}\right), 35.0\left(\mathrm{CH}_{2}\right), 45.0(\mathrm{CH}), 48.5\left(\mathrm{CH}_{2}\right), 125.9$ $(\mathrm{CH}), 127.0(\mathrm{CH}), 127.3(\mathrm{CH}), 127.8(\mathrm{CH}), 128.3(\mathrm{CH}), 128.35$ $(\mathrm{CH}), 129.0(\mathrm{CH}), 129.6(\mathrm{CH}), 137.0(\mathrm{C}), 141.0(\mathrm{C}), 141.5(\mathrm{C})$, $143.3(\mathrm{C}) ; v_{\max }\left(\mathrm{CH}_{2} \mathrm{Cl}_{2} / \mathrm{cm}^{-1}\right) 3360,2043,2932,1599,1493$, $1431,1327,1222,1159,1087,810 ; \mathrm{m} / z(\mathrm{ES})$ required 380.1666 $\left(\mathrm{MH}^{+}, 100 \%\right)$; found 380.1684 (-4.8 ppm).

\section{Crystallographic data}

Crystal structural data for compound 7a: $\mathrm{C}_{10} \mathrm{H}_{9} \mathrm{NO}_{3} \mathrm{~S} ; M=$ 223.24; orthorhombic, Pbca; $a=8.9434(12) \AA, b=12.1447$ (16) $\AA, c=17.0400(2) \AA ; U=1850.8(4) \AA^{3} ; T=100(2) \mathrm{K} ; Z=8$; 15241 reflections measured, 2019 unique $\left(R_{\text {int }}=0.0514\right)$. The final $w R^{2}$ was 0.1169 (all data). CCDC reference number 742466. Crystal structure data for compound 13a: $\mathrm{C}_{10} \mathrm{H}_{9} \mathrm{NO}_{2} \mathrm{SBr}_{2} ; M=367.06$; monoclinic, $P 2{ }_{1} / c ; a=$ 11.1268(11) $\AA, b=8.6567(8) \AA, c=12.5715(12) \AA ; U=$ $1129.8(19) \AA^{3} ; T=100(2) \mathrm{K} ; Z=4 ; 11016$ reflections measured, 2808 unique $\left(R_{\text {int }}=0.0407\right)$. The final $w R^{2}$ was 0.0671 (all data). CCDC reference number 742467. Crystal structural data for compound $\mathbf{1 8 b}: \mathrm{C}_{12} \mathrm{H}_{13} \mathrm{NO}_{4} \mathrm{SBr}_{2} ; M=427.11$; monoclinic, $P 2_{1} / n ; a=11.462(2) \AA, b=10.4508(18) \AA, c=$ 12.0450(2) $\AA ; U=1405.2(4) \AA^{3} ; T=100(2) \mathrm{K} ; Z=4 ; 11889$ reflections measured, 2867 unique $\left(R_{\text {int }}=0.0378\right)$. The final $w R^{2}$ was 0.0946 (all data). CCDC reference number 742468 . Crystal structural data for compound 19b: $\mathrm{C}_{13} \mathrm{H}_{16} \mathrm{NO}_{5} \mathrm{SBr} ; M=$ 378.24; monoclinic, $P 2{ }_{1} / c ; a=15.9581(19) \AA, b=10.6318(13)$ $\AA, c=17.8100(2) \AA ; U=2889.5(6) \AA^{3} ; T=100(2) \mathrm{K} ; Z=8$; 65857 reflections measured, 8789 unique $\left(R_{\text {int }}=0.0329\right)$. The final $w R^{2}$ was 0.0712 (all data). CCDC reference number 742469. Crystal structural data for compound 26: $\mathrm{C}_{11} \mathrm{H}_{11} \mathrm{NO}_{4} \mathrm{~S}$;
$M=253.27$; monoclinic, $P 2{ }_{1} / n ; a=14.7519(16) \AA, b=$ 9.6485(10) $\AA, c=15.2476(16) \AA ; U=2163.8(4) \AA^{3} ; T=100(2)$ $\mathrm{K} ; Z=8 ; 37265$ reflections measured, 4487 unique $\left(R_{\text {int }}=\right.$ 0.0384 ). The final $w R^{2}$ was 0.1158 (all data). CCDC reference number 742471. Crystal structural data for compound 31: $\mathrm{C}_{16} \mathrm{H}_{15} \mathrm{NO}_{2} \mathrm{~S} ; M=285.35$; orthorhombic, $P 2{ }_{1}{ }_{2}{ }_{2}{ }_{1} ; a=$ 9.3949(7) $\AA, b=10.7576(8) \AA, c=13.5221(10) \AA ; U=$ 1366.63(18) $\AA^{3} ; T=180(2) \mathrm{K} ; Z=4 ; 16599$ reflections measured, 4468 unique $\left(R_{\mathrm{int}}=0.0157\right)$. The final $w R^{2}$ was 0.0852 (all data). CCDC reference number 742470 .

\section{Supporting Information}

Supporting information features experimental procedures and spectroscopic analyses for compounds $6 \mathbf{a}, \mathbf{6 b}, 7 \mathbf{a}, 7 \mathbf{b}$, 13a, 13b, 16a, 16b, 17a, 18b, 19b, 24a, 24b, 25-37, and 39.

\section{Supporting Information File 1}

Diastereoselective functionalisation of benzo-annulated bicyclic sultams: application for the synthesis of cis-2,4-diarylpyrrolidines.

[http://www.beilstein-journals.org/bjoc/content/ supplementary/1860-5397-5-69-S1.pdf]

\section{Acknowledgements}

We would like to acknowledge UCD for the provision of a postgraduate scholarship. Additionally Dr. Helge Müller-Bunz is thanked for X-ray crystallography and Dr. Jimmy Muldoon is thanked for assistance with NMR spectroscopy.

\section{References}

1. Evans, P.; McCabe, T.; Morgan, B. S.; Reau, S. Org. Lett. 2005, 7, 43-46. doi:10.1021/ol0480123

2. Evans, P. J. Org. Chem. 2007, 72, 1830-1833. doi:10.1021/jo062189o

3. Kelleher, S.; Muldoon, J.; Müller-Bunz, H.; Evans, P. Tetrahedron Lett. 2007, 48, 4733-4736. doi:10.1016/j.tetlet.2007.05.015

4. Zeng, W.; Chemler, S. R. J. Org. Chem. 2008, 73, 6045-6047. doi:10.1021/jo801024h

5. Knowles, J. P.; Whiting, A. Org. Biomol. Chem. 2007, 5, 31-44. doi:10.1039/b611547k (see for recent reviews)

6. Zeni, G.; Larock, R. C. Chem. Rev. 2006, 106, 4644-4680. doi:10.1021/cr0683966 (see for recent reviews)

7. Gibson, S. E.; Middleton, R. J. Contemp. Org. Synth. 1996, 3, 447-471. doi:10.1039/CO9960300447 (see for recent reviews).

8. Dounay, A. B.; Overman, L. E. Chem. Rev. 2003, 103, 2945-2964. doi:10.1021/cr020039h

(see for recent reviews). 
9. Link, J. T. Org. React. 2002, 60, 157-534. doi:10.1002/0471264180.or060.02 (see for recent reviews).

10. Grigg, R.; Sridharan, V.; York, M. Tetrahedron Lett. 1998, 39 , 4139-4142. doi:10.1016/S0040-4039(98)00709-6

11. de Vries, A. H. M.; Mulders, J. M. C. A.; Mommers, J. H. M.; Henderickx, H. J. W.; de Vries, J. G. Org. Lett. 2003, 5, 3285-3288. doi:10.1021/ol035184b

12. McAlonan, H.; Montgomery, D.; Stevenson, P. J. Tetrahedron Lett. 1996, 37, 7151-7154. doi:10.1016/0040-4039(96)01564-X

13. Bielawski, C. W.; Louie, J.; Grubbs, R. H. J. Am. Chem. Soc. 2000, 122, 12872-12873. doi:10.1021/ja001698j

14. Leclerc, J.-P.; André, M.; Fagnou, K. J. Org. Chem. 2006, 71, 1711-1714. doi:10.1021/jo0523619

15. Ibarguren, O.; Zakri, C.; Fouquet, E.; Felpin, F.-X. Tetrahedron Lett. 2009, 50, 5071-5074. doi:10.1016/j.tetlet.2009.06.084

16. Fenster, M. D. B.; Dake, G. R. Org. Lett. 2003, 5, 4313-4316. doi:10.1021/ol035566h

17. Yang, D.; Wong, M.-K.; Yip, Y.-C. J. Org. Chem. 1995, 60, 3887-3889. doi:10.1021/jo00117a046

18. Kamenecka, T. M.; Danishefsky, S. J. Chem.-Eur. J. 2001, 7, 41-63. doi:10.1002/1521-3765(20010105)7:1<41::AID-CHEM41>3.0.CO;2-D

19. Li, S.; Yamamura, S. Tetrahedron 1998, 54, 8691-8710. doi:10.1016/S0040-4020(98)00479-7

20. Dura, R. D.; Paquette, L. A. J. Org. Chem. 2006, 71, 2456-2459. doi:10.1021/j00526587

21. Berti, G.; Marsili, A. Tetrahedron 1966, 22, 2977-2988. doi:10.1016/S0040-4020(01)82275-4 (see for example).

22. Speckamp, W. N.; Moolenaar, M. J. Tetrahedron 2000, 56, 3817-3856. doi:10.1016/S0040-4020(00)00159-9

23. Ungureanu, I.; Bologa, C.; Chayer, S.; Mann, A. Tetrahedron Lett. 1999, 40, 5315-5318. doi:10.1016/S0040-4039(99)01002-3

24. Qiu, J.; Silverman, R. B. J. Med. Chem. 2000, 43, 706-720. doi:10.1021/jm9904755

25. Blanchet, J.; Macklin, T.; Ang, P.; Metallinos, C.; Snieckus, V. J. Org. Chem. 2007, 72, 3199-3206. doi:10.1021/jo062385v

26. Seto, H.; Fujioka, S.; Koshino, H.; Suenaga, T.; Yoshida, S.; Watanabe, T.; Takatsuto, S. J. Chem. Soc., Perkin Trans. 11998 , 3355-3358. doi:10.1039/a805945d

\section{License and Terms}

This is an Open Access article under the terms of the Creative Commons Attribution License (http://creativecommons.org/licenses/by/2.0), which permits unrestricted use, distribution, and reproduction in any medium, provided the original work is properly cited.

The license is subject to the Beilstein Journal of Organic Chemistry terms and conditions: (http://www.beilstein-journals.org/bjoc)

The definitive version of this article is the electronic one which can be found at: doi:10.3762/bjoc.5.69 